\title{
Sudska medicina i Medicinski fakultet Sveučilišta u Zagrebu (1922. - 1945.)
}

\author{
MARKO KOLIĆ \\ Zagreb, Hrvatska \\ okramcilok@gmail.com
}

\begin{abstract}
Autor je u radu analizirao položaj sudske medicine na Medicinskom fakultetu Sveučilišta u Zagrebu. Rad je podijeljen u nekoliko cjelina u kojima se problematizira položaj sudske medicine prije i nakon osnutka Medicinskoga fakulteta. Poseban naglasak stavljen je na Zavod za sudsku medicinu i kriminalistiku, čijim je osnutkom postavljen temelj za sustavni razvoj ove grane medicine u Hrvatskoj. U osnivanju Zavoda središnju ulogu imao je Eduard Miloslavić, forenzičar koji je svjetsku slavu postigao u Sjedinjenim Američkim Državama. Glavni je cilj rada sustavnije prikazati razvoj sudske medicine u Hrvatskoj tijekom prve polovine XX. stoljeća s naglaskom na zagrebački Medicinski fakultet.
\end{abstract}

Ključne riječi: sudska medicina; Zavod za sudsku medicinu i kriminalistiku; Eduard Miloslavić; Medicinski fakultet Sveučilišta u Zagrebu

Razvoj sudske medicine u Hrvatskoj još uvijek nije dovoljno dobro istražen. Najviše se pisalo o Eduardu Miloslaviću, osnivaču i prvom predstojniku Zavoda za sudsku medicinu i kriminalistiku. Miloslavić je historiografski zanimljiv jer je bio i član međunarodne komisije koja je istraživala zločine u Katynskoj šumi. Od hrvatskih autora koji su o njemu pisali svakako treba istaknuti Marija Jareba, Vladimira Dugačkog i Stellu Fatović-Ferenčić. ${ }^{1}$ S

\footnotetext{
1 Mario Jareb objavio je 2019. knjigu Sovjetski zločin u Katynskoj šumi, u kojoj je na 335 stranica opsežno obradio Miloslavićev život i rad i njegovu ulogu u istraživanju sovjetskih zločina u Katynskoj šumi. Vladimir Dugački i Stella Fatović-Ferenčić objavili su više različitih radova koji se bave Miloslavićem. Osobito je važan njihov zajednički rad „Ljudevit Jurak (1881-1952) and Eduard Miloslavić (1884-1952). Founders of Croatian pathological and forensic medicine and experts at the investigations of mass graves at Katyn and Vinnitsa During World War II", u: Katyn and Switzerland. Forensic Investigators and Investigations in Humanitarian Crises 1920-2007, ur. Delphine Debons, Antoine Fleury i Jean-François Pitteloud (Geneve: Georg Editeur, Editions m+h, 2009), 189-201. Osim toga Fatović-Ferenčić je u suautorstvu s Darijom Hofgräff i Slavenom Kaleom objavila rad „Istraživanja patološkog anatoma Eduarda Miloslavića na bojištima Drugoga balkanskog i Prvoga svjetskog rata”, Anali Zavoda za znanstveni i umjetnički rad u Osijeku 30 (2014): 45-62. Fatović-Ferenčić napisala je i različite prikaze razvoja sudske medicine tijekom povijesti u Hrvatskoj, među kojima se može istaknuti „Uvod” u: ZEČEVIĆ et al., Sudska medicina i deontologija.
} 
druge strane o razvoju sudske medicine na prostoru Hrvatske tijekom XIX. i XX. stoljeća još uvijek nisu napravljene sustavne analize. No postoje radovi koji su se time bavili u manjem opsegu ili su se na druge načine doticali te teme. Tu treba izdvojiti monografije Medicinskoga fakulteta Sveučilišta u Zagrebu u kojima se mogu pronaći različiti podaci važni za razvoj Zavoda za sudsku medicinu i kriminalistiku. Usto treba istaknuti autore poput Vladimira Bazale i Lavoslava Glesingera, čijim sam se knjigama koristio i u pisanju ovoga rada. Navedena literatura i autori najčešće su se samo doticali razvoja sudske medicine na Medicinskom fakultetu bez dublje analize. Stoga je glavni cilj ovoga rada dati sustavniji prikaz razvoja sudske medicine na Medicinskom fakultetu s naglaskom na razdoblje od 1922. do 1945. godine. Pritom mi je uz dostupnu literaturu od velike pomoći bio arhiv Medicinskoga fakulteta Sveučilišta u Zagrebu te arhiv Sveučilišta u Zagrebu. ${ }^{2}$

\section{Sudska medicina prije Medicinskoga fakulteta}

Sudska medicina je grana medicine koja se bavi uzrokom, mehanizmom i načinima smrti. ${ }^{3}$ Osim toga bavi se problemima nasilnoga oštećenja zdravlja, a osnovna joj je svrha pružanje pomoći pravnoj struci da bi se u sudskom postupku uspješno riješili problemi medicinske naravi. ${ }^{4}$ Kao i druge medicinske grane, najveći napredak doživljava u XIX. stoljeću. Tada je ostvaren važan iskorak uvođenjem kemijskih i bioloških metoda u sudskomedicinska istraživanja. Tome treba dodati i razvoj kriminalne antropologije i sudske psihijatrije, za što su najzaslužniji bili talijanski psihijatar Cesare Lombroso i francuski kriminalist Alexandre Lacassagne. ${ }^{5}$

Iako važne promjene za medicinu počinju u XIX. stoljeću, neki bitni iskoraci učinjeni su i prije. Tu prije svega treba istaknuti habsburške vladare Mariju Tereziju i Josipa II. U historiografiji je općepoznato da je tijekom njihove vladavine proveden niz reformi s ciljem modernizacije države na temelju prosvjetiteljskih ideja. Među tim reformama bile su i one vezane uz javno zdravstvo. Prema povjesničarki Ivani Horbec, od 1753. do 1787. doneseno je ukupno šest ključnih normativnih akata važnih za razvoj javnoga zdravstva u Monarhiji. ${ }^{6}$ Među njima treba istaknuti jedan od najvažnijih normativnih izvora za povijest habsburškoga zdravstva uopće, Generale normativum sa-

\footnotetext{
2 Ovim putem zahvaljujem dekanu Medicinskoga fakulteta prof. dr. sc. Marijanu Klarici na dopuštenju za rad u arhivu. Zahvaljujem i doc. dr. sc. Vlatki Lemić, rukovoditeljici Središnjega ureda za arhivsku građu na Sveučilištu u Zagrebu.

ZEČEVIĆ et al., Sudska medicina i deontologija, 3-4.

4 Vidi: „Sudska medicina”.

5 GLESINGER, Povijest medicine, 148.

6 Radi se o sljedećim normativnim aktima: Medicinski pravilnik za Kraljevinu Češku, Opći zdravstveni pravilnik za Austrijsko primorje, Regulacija rada Zdravstvenog povjerenstva u Karlovačkom generalatu, Opći zdravstveni pravilnik, Dodatak Općem zdravstvenom pravilniku i Službena uputa za županijske fizike i kirurge. HORBEC, Zdravlje naroda - bogatstvo države, 78-83.
} 
nitatis ili Opći zdravstveni pravilnik iz 1770. godine. Tim je pravilnikom, među ostalim, bilo definirano i mrtvozorstvo kao preteča današnje sudske medicine. Središnje mjesto dobili su liječnici i kirurzi. Glavna obveza kirurga bila je svaku sumnju na nasilno ranjavanje ili smrt prijaviti mjesnim vlastima. Također, kirurzi su morali na zahtjev liječnika sudjelovati na sudskoj obradi obdukcije, obaviti anatomske zahvate i u suradnji s liječnikom sastaviti izvještaj o tome. ${ }^{7}$ Odredbe su se doticale i ljekarnika i primalja, koji su također imali obveze vezane uz sudskomedicinska vještačenja. Primjerice, primalje su mogle obavljati sudskomedicinsko vještačenje ako se sumnjalo na pobačaj. ${ }^{8}$ Važan iskorak napravljen je i 1779., kad je Marija Terezija osnovala medicinsku policiju. Ona se uz ostalo bavila pitanjem mrtvozorstva. Liječnik i povjesničar medicine Dubravko Habek navodi kako je „medicinska policija bila temelj razvoja sudske medicine i kriminalistike u suradnji sa zdravstvenim osobljem koristeći njihova znanja". ${ }^{9}$ Krajem XVIII. stoljeća počinju se osnivati i prosekture kao zasebne zdravstvene institucije, što će dati važan poticaj daljnjem razvoju moderne sudske medicine.

Moderna sudska medicina u Zagrebu se počela razvijati u drugoj polovini XIX. stoljeća. Naime, u sklopu današnjega Pravnog fakulteta Sveučilišta u Zagrebu 1861. počela se izvoditi nastava iz sudske medicine. Prvi profesor bio je liječnik Mavro Sachs. ${ }^{10}$ Nastava je osim teorijskoga dijela obuhvaćala eksperimente iz kemijske toksikologije i obdukcije u svrhu edukacije. Sachs je držao nastavu do 1888., kada ga je na katedri naslijedio profesor Kraljevske primaljske škole i ravnatelj rodilišta Antun Lobmayer, koji će na toj funkciji ostati do 1906. godine. ${ }^{11}$ Njega je naslijedio Danijel Riessner. ${ }^{12}$ Paralelno s Riessnerom nastavu iz sudske medicine držao je i Ernest Miler. Po osnutku Medicinskoga fakulteta u Zagrebu Miler će u suradnji s Ljudevitom Jurakom

Isto, 181.

8 HABEK, „Prilog povijesti sudske medicine i mrtvozorstva u gradu Bjelovaru”, 464.

9 Isto.

10 Prva predavanja iz sudske medicine Sachs je u Zagrebu držao 1849. u sklopu pravnoga studija Kraljevske akademije znanosti u Zagrebu, no ona je 1850. bila ukinuta. Stoga se 1861 . uzima kao početak nastave iz sudske medicine s obzirom na to da se otada do danas ona kontinuirano izvodi na Sveučilištu u Zagrebu. Sachs je ujedno bio prvi docent iz medicine na Sveučilištu u Zagrebu. DUGAČKI, „Dr. Mavro Sachs”, 377-380; ZEČEVIĆ et al., Sudska medicina i deontologija, 5.

11 Antun Lobmayer (1844. - 1906.) istaknuo se kao zdravstveni prosvjetitelj koji je objavio stotinjak članaka o higijeni, zaraznim bolestima, podizanju djece i prvoj pomoći, udžbenik za primalje te 30-ak knjiga, od kojih su najpopularnije bile Kućni liječnik i Čovjek i njegovo zdravlje. Vidi: „Lobmayer, Antun”; BERIĆ, BABIĆ, „Dr. Antun Lobmayer”, 113-118; BAZALA, Poviestni razvoj medicine u hrvatskim zemljama, 169-170; DUGAČKI, „Medicinska nastava u Zagrebu", 113, 116-118.

12 Riessner će 1920. postati i izvanredni profesor. Uz nastavu iz sudske medicine držat će i mnoge druge kolegije, primjerice Pometnuće i čedomorstvo, Otrovanja, Seksualni delikti u sudskoj medicini, Uzroci i vrste silovite i naprasne smrti, Metode i predmeti forenzičko-medicinskih istraživanja, Pregled forenzičke psihijatrije. DUGAČKI, „Medicinska nastava u Zagrebu", 118. 
držati i nastavu iz sudske medicine sve do smrti 1928. godine. ${ }^{13}$ No o tome će više riječi biti poslije.

Ne čudi stoga da su do osnutka Medicinskoga fakulteta 1917. već postojale publikacije koje su postavile temelj za razvoj sudske medicine u Hrvatskoj. Jedan od prvih radova za to područje medicine u Hrvatskoj praktične su upute za sastavljanje sudskomedicinskih zapisnika koje je Ivan Dežman objavio 1886. pod naslovom Lěčnička izvěšća (Visa reperta): za praktičnu porabu lěčnikov. ${ }^{14}$ Tri godine poslije Niko Selak izdao je u Koprivnici prvu knjigu o sudskoj medicini na hrvatskom jeziku - Kratka sudska medicina. Iako se radi o nevelikoj knjizi, u njoj su obrađeni najvažniji problemi iz sudske medicine s naglaskom na praktičnim primjerima. ${ }^{15}$ Publicistička aktivnost nastavit će se i na početku XX. stoljeća, a osobito treba istaknuti tri autora. Prvi je Ernest Miler, koji je 1902. objavio knjigu Kriminalno-pravna odgovornost liečnika. Sljedeći važan autor bio je Božo Peričić, koji je 1903. izdao Sudsko liječnički razgled mrtvaca, koji je doživio i drugo izdanje 1919. u Zagrebu. U Trogiru će pak 1911. Leonard Celio Cega izdati Kratku sudsku psihopatologiju. ${ }^{16}$

Važan iskorak u daljnjem razvoju sudske medicine u Zagrebu napravljen je 1913. otvaranjem Prosekture javnih zdravstvenih zavoda grada Zagreba. Prvi predstojnik Prosekture bio je Ljudevit Jurak. ${ }^{17}$ Osnutak Prosekture smatra se početkom organiziranoga razvoja patologije u Hrvatskoj. ${ }^{18}$ No Prosektura je imala vrlo važnu ulogu i u razvoju sudske medicine. Jurak se do dolaska u Zagreb, osim u patologiji, usavršavao i u sudskoj medicini. Stoga ne čudi da je prilikom preuzimanja dužnosti predstojnika Prosekture, uz patološke, počeo obavljati i sudskomedicinske obdukcije. Dio sudskomedicinskih poslova nakon osnutka preuzet će i Zavod za patologiju Medicinskoga fakulteta Sveučilišta u Zagrebu. Tamo će sudskomedicinske obdukcije, među ostalima,

13 Ernest Miler (1866. - 1928.), hrvatski sociolog, pravnik i kriminolog. Smatra se začetnikom sociologije u Hrvatskoj jer je osnovao prvu katedru sociologije u Austro-Ugarskoj Monarhiji. Bio je dekan Pravnoga fakulteta u Zagrebu te rektor i prorektor Sveučilišta u Zagrebu. Vidi: „Miler, Ernest”.

14 VITALE, Četiri stoljeća javnog zdravstva i biomedicine u Hrvatskoj, 339.

15 Isto.

16 BAZALA, Poviestni razvoj medicine u hrvatskim zemljama, 184; VITALE, Četiri stoljeća javnog zdravstva i biomedicine u Hrvatskoj, 339.

17 Ljudevit Jurak (1881. - 1945.), hrvatski patolog i forenzičar. Smatra ga se ocem hrvatske humane i animalne patologije. Gimnaziju je završio u Zagrebu 1902., a studij medicine u Innsbrucku 1910. Od 1911. do 1914. bio je asistent na Zavodu za patološku anatomiju Sveučilišta u Innsbrucku i suradnik tamošnjega Zavoda za sudsku medicinu. Osim što je obnašao funkciju predstojnika u Prosekturi, bio je i suradnik Medicinskoga fakulteta Sveučilišta u Zagrebu kao profesor sudske medicine od 1923. do 1932. i profesor patologije na Veterinarskom fakultetu Sveučilišta u Zagrebu. Juraku u čast Prosektura na čijem je čelu bio danas nosi naziv Klinički zavod za patologiju i citologiju „Ljudevit Jurak”. Od 1990. Klinički zavod organizator je međunarodnoga znanstvenog skupa Ljudevit Jurak International Symposium on Comparative Pathology, na kojem se svake godine među ostalim dodjeljuje i nagrada "Ljudevit Jurak”. Vidi: "Jurak, Ljudevit”; BELICZA, KRUŠLIN, 100 godina Kliničkog zavoda za patologiju, 7, 81-129.

18 BELICZA, ŠAIN, „Uloga i doprinos Hrvatskog liječničkog zbora”, 349. 
obavljati i patolozi Marcel Kornfeld i Sergej Saltykow te kirurg Julije Budisavljević. Tako će ostati do 1934. i osnivanja Zavoda za sudsku medicinu i kriminalistiku, kad se tamo počinju obavljati sve sudskomedicinske obdukcije. ${ }^{19}$

\section{Medicinski fakultet u Zagrebu i sudska medicina}

\section{Rasprave o otvaranju fakulteta i položaj sudske medicine}

Preteča zagrebačkoga sveučilišta bila je Isusovačka akademija u Zagrebu, koja je 1669. od habsburškoga vladara Leopolda I. dobila sveučilišne privilegije. Raspuštanjem isusovačkoga reda država preuzima svu njihovu imovinu, pa i zagrebačku akademiju. Rad akademije obnovljen je 1776., kad je osnovana Kraljevska akademija znanosti s tri fakulteta: teološkim, pravnim i filozofskim. Bio je to ujedno početak nastojanja za osnivanje medicinskoga studija. Naime, 1790. profesorski zbor Akademije uputio je Hrvatskom saboru predstavku u kojoj se molilo da se Akademija uzdigne na stupanj sveučilišta. No u slučaju da to ne bi bilo moguće, istaknuto je da se onda pokrene studije medicine ili barem kirurgije. ${ }^{20}$ Međutim, tada nijedno od toga nije bilo ostvareno, a te će težnje doći do izražaja i u kasnijim desetljećima.

Rasprave o medicinskom studiju snažnije će se intenzivirati osnivanjem modernoga sveučilišta u Zagrebu 1874. godine. Tom je prilikom donesen $\mathrm{Za}$ kon ob ustrojstvu i uređenju sveučilišta Franje Josipa I. u Zagrebu, kojim su bile određene sljedeće sastavnice: bogoslovni (teološki), pravoslovni (pravni) i mudroslovni (filozofski) fakultet. ${ }^{21}$ Tim je zakonom bilo određeno da studij medicine traje pet godina. Sudska medicina trebala se slušati na trećoj godini, zajedno s patološkom anatomijom, posebnom liječničkom patologijom, terapijom i klinikom, naukom o kirurškim oruđima i zavojima, liječničkim redarstvom te posebnom kirurškom patologijom, terapijom i klinikom. ${ }^{22}$ No, kao što je poznato, fakultet tada nije otvoren. Jedna od glavnih prepreka toj ideji svakako je bila i politička situacija. Dugački navodi kako su glavni problem bili Beč i Pešta, „koji nisu željeli da se u Hrvatskoj stvori još jedan kadar nezavisnih slobodoumnih intelektualaca”. ${ }^{23}$ I financije su bile veliki problem, koji će do izražaja dolaziti i nakon što je Medicinski fakultet u Zagrebu osnovan. Međutim, sve do 1917., kada je osnivanje fakulteta napokon realizirano, postojale su različite inicijative koje su se intenzivno zalagale za to.

Među tim inicijativama svakako treba spomenuti predstavku iz 1888. izdanu povodom 40. obljetnice vladavine Franje Josipa I. Njezina osnovna svr-

19 HR-MEF, Opći spisi (1918. - 1952.) (dalje: OS), K broju 936/1934. SAVJETU MEDICINSKOG FAKULTETA u Zagrebu.

20 ČEČUK, BELICZA, ŠKRBIĆ, Medicinski fakultet Sveučilišta u Zagrebu, 7.

21 Vidi: „Sveučilište”.

22 Kraljevsko sveučilište Franje Josipa I. u Zagrebu, 206.

23 DUGAČKI, „Medicinska nastava u Zagrebu”, 114. 
ha bila je objasniti važnost pokretanja medicine u Zagrebu. Uz Sbor liječnika Kraljevine Hrvatske i Slavonije ${ }^{24}$, tu su inicijativu podržali i liječnik Eduard Albert i botaničar Bohuslav Jiruš. „Predstavka“ je i dalje predviđala da nastava medicine traje pet godina, a sudska medicina trebala se slušati na trećoj godini. Svjestan financijske situacije, Jiruš je predlagao da se teorijski predmeti mogu smjestiti u jednu zgradu. Prema tome, anatomija, fiziologija, patologija, sudska medicina, farmakologija, opća patologija, nauk o životinjskim bolestima, kemija, embriologija te higijena mogli bi biti u jednoj zgradi. Jiruš je držao da je za tu svrhu najprikladnija zgrada današnjega Rektorata. ${ }^{25}$ Albert se slagao s Jiruševim prijedlozima uz neke dodatke. On je smatrao da u početku profesor patologije bez problema može držati nastavu iz sudske medicine. Osim toga vjerovao je da trenutačna nestašica novca ne mora nužno onemogućiti napredak u medicinskim znanostima. Za primjer je naveo Eduarda von Hofmanna, koji je došao do važnih otkrića na polju sudske medicine u vrlo skromnim uvjetima. ${ }^{26}$ No ni ta nastojanja nisu urodila plodom.

Rasprave o otvaranju medicinskoga fakulteta u Zagrebu ponovno su se intenzivirale za vrijeme Prvoga svjetskog rata. Ratne strahote i opća nestašica liječnika učvrstile su stavove da se medicinski fakultet u Zagrebu mora realizirati. ${ }^{27}$ To se osjetilo i u javnom prostoru, gdje se ponovno intenzivno raspravljalo o budućem fakultetu. Tu osobito treba istaknuti dvojicu liječnika koji su se u svojim promišljanjima dotaknuli i položaja sudske medicine. Prvi je bio češki patolog Jaroslav Hlava. Svjestan financijskoga izazova koji donosi otvaranje medicinskoga fakulteta, Hlava je isticao da bi najprije trebalo pristupiti izgradnji teorijskih zavoda koji su ključni za prve godine studija. Zatim bi trebalo razvijati kliniku, ovisno o financijskim mogućnostima. U „prvoj etapi trebalo bi izgraditi institut za normalnu anatomiju, za histologiju i embriologiju, za opću i specijalnu fiziologiju, te institut za opću patologiju i farmakologiju, za patološku anatomiju s patološkom histologijom i bakteriologijom, konačno za sudsku medicinu i higijenu. Bio bih odlučno zato, da se grade zasebni instituti, jer mnogo gospodara i sluga u jednoj kući teško je vladati”. ${ }^{28}$ Drugi liječnik bio je Miroslav Čačković, jedan od osnivača Medi-

\footnotetext{
24 Danas se to udruženje zove Hrvatski liječnički zbor.

25 Rektorat Sveučilišta u Zagrebu nalazi se na adresi Trg Republike Hrvatske 14, 10000 Zagreb.

26 Prilikom istraživanja u HDA i sveučilišnom arhivu naišao sam na „Predstavku“ sačuvanu u dva različita formata. U sveučilišnom arhivu čuva se primjerak „Predstavke“ u rukopisu radi čega se može pretpostaviti kako je tamo i sastavljena. S druge pak strane u HDA se nalazi primjerak tiskanog izdanja „Predstavke“ koja sadržajem potpuno odgovara onoj koja se nalazi u sveučilišnom arhivu. Inače, „Predstavka“ se nalazi u sklopu zbirke Farmaceutski spisi i spisi praliječnika (HR-HDA-892). Stoga se može pretpostaviti kako je ista tiskana i dijeljena svima koji su bili zainteresirani za problematiku vezanu uz pokretanje medicinskog fakulteta na Sveučilištu u Zagrebu. „Predstavka što nu ju je upravio akademički senat našeg sveučilišta na preuzv. gosp. bana i na sabor, kojom moli. da se u spomen 40 -godišnice Njeg. Veličanstva ustroji na zagrebačkom sveučilištu medicinski fakultet”, 11-27.

27 DUGAČKI, REGAN, „Zagreb u Prvom svjetskom ratu”, 97-120.

28 HLAVA, „K ustrojenju novog medicinskog fakulteta u Zagrebu”, 144.
} 
cinskoga fakulteta i središnja ličnost hrvatske medicine toga vremena. ${ }^{29}$ Svjestan situacije, Čačković je o izgradnji budućih zavoda napisao: „Za medicinski se fakultet upotrebljavaju od postojećih sveučilišnih instituta: prirodopisni, fizikalni, kemijski i farmakognostički filozofskog fakulteta, gradi se posebna zgrada u koju se smješta sistemska anatomija, patološka anatomija i sudska medicina [...]." ${ }^{30}$ Iz ove se izjave može iščitati jedan važan argument. Naime, Čačković je bio jedan od onih koji su predlagali da sudska medicina bude u istoj zgradi kao i patologija. Takvo je rješenje bilo i u Osnovi zakona o gradnji zgrada za medicinski fakultet i zemaljsku bolnicu s klinikama u Zagrebu. Ta je osnova predviđala da se u šest godina izgradi cijeli fakultet sa svim potrebnim klinikama i zavodima. Gradnja zgrade zavoda za patološku anatomiju i histologiju i zavoda za sudsku medicinu bila je zamišljena u trećoj godini, a predviđeni troškovi iznosili su 600.000 kruna. ${ }^{31}$ Međutim, taj projekt nije realiziran. Osim toga, iako je zgrada Zavoda za patologiju djelomično bila izgrađena, Zavod za sudsku medicinu i kriminalistiku nije se smjestio u nju.

\section{Medicinski fakultet i sudska medicina do 1932.}

Otvaranje Medicinskoga fakulteta 1917. označilo je novu stranicu u razvoju hrvatske medicine. Međutim, da bi fakultet profunkcionirao, trebalo je zadovoljiti dva ključna elementa: osigurati potrebne prostorne kapacitete i odgovarajuće nastavno osoblje. To će se u slučaju sudske medicine pokazati izazovom koji će se riješiti tek početkom 30-ih godina.

Odabir profesorskoga kadra pokazao se vrlo zahtjevnim zadatkom, iako to nije uvijek bio slučaj. Tako je već po osnutku fakulteta za profesora anatomije izabran Drago Perović, a za profesora farmakologije i patofiziologije Miroslav Mikuličić. S druge strane profesor patologije izabran je tek iz trećega pokušaja, kad je 1922. na to mjesto došao Sergej Saltykow. ${ }^{32}$ Situacija s izborom profesora sudske medicine bila je još i teža. Dugački kaže da se biralo među više kandidata, poput Muller-Hessa, Molitorisa i Rolla, no nijedan od njih nije se odazvao pozivu. ${ }^{33}$ Uz njih je jedan od kandidata bio i Eduard Miloslavić, ali je zbog neslaganja s pojedinim političarima i liječnicima bio odbačen kao opcija. Iz toga je vremena osobito važan bio sukob s liječnikom Jakšom Miličićem, koji je 1920. u splitskom dnevniku Novo doba objavio članak u kojemu je iznio

${ }^{29}$ Jedan je od osnivača hrvatske neurokirurgije, rendgenologije i reanimacije. Uz Teodora Wickerhausera i Dragutina Mašeka smatra se osnivačem Medicinskoga fakulteta u Zagrebu, čiji je ujedno bio prvi dekan. Vidi: „Čačković Vrhovinski, Miroslav”; DUGAČKI, REGAN, „Zagreb u Prvom svjetskom ratu”, 97-120.

30 ČAČKOVIĆ, „Kako da uredimo naš medicinski fakultet?”, 148.

31 „Osnova zakona o gradnji zgrada za medicinski fakultet i zemaljsku bolnicu s klinikama u Zagrebu", 153-154.

32 "Sergej Saltykow i njegov dolazak na Zavod za patologiju”.

33 DUGAČKI, „Eduard Miloslavić, Zmaj od svete Mandaljene”, 14. 
niz optužbi na Miloslavićev račun. ${ }^{34}$ Miličić ga je među ostalim optuživao za protujugoslavensko djelovanje i podržavanje Austro-Ugarske Monarhije. Jareb smatra da su upravo Miličićeve optužbe imale ključnu ulogu u tome da se Miloslavića odbaci kao potencijalnoga kandidata za profesora sudske medicine. Jareb navodi i da je to bitno odredilo njegov daljnji životni put. ${ }^{35}$ Naime, Miloslavić je nedugo nakon tih događaja 1921. prihvatio poziv iz Sjedinjenih Američkih Država (SAD), gdje će ostvariti međunarodno priznatu karijeru na polju sudske medicine, ${ }^{36}$ a u Zagreb će se vratiti tek početkom 30 -ih godina.

Drugi problem bili su nedostatni prostorni kapaciteti potrebni za osnivanje još jednoga zavoda na Šalati. ${ }^{37} \mathrm{U}$ raspravama i zakonskim prijedlozima nastalima povodom i u svrhu otvaranja Medicinskoga fakulteta najviše se razmatrala opcija da sudska medicina bude smještena u zgradi s patologijom. No to se neće realizirati. Smatram da su na to utjecala dva ključna razloga. Prvi je bio taj što zgrada sagrađena za Zavod za patologiju nije nikad dovršena. Veći dio građevinskih radova na toj zgradi napravljen je do 1922., nakon čega dolazi do zastoja prouzrokovanog lošom financijskom situacijom. ${ }^{38}$ Posljedica je bila da planirano istočno krilo zgrade nije nikad dovršeno, što je stvaralo velike probleme u kasnijem funkcioniranju Zavoda. ${ }^{39}$ Drugi razlog, kako se čini iz dostupne arhivske građe, bio je sam predstojnik Zavoda za patologiju Sergej Saltykow. Iako sačuvano arhivsko gradivo o tome ne govori mnogo, čini se da je i u prvim godinama fakulteta još uvijek prevladavala ideja da se u sklopu zgrade Zavoda za patologiju pokrene i sudska medicina. Međutim, Saltykow je pri svojem dolasku odbacio takvu mogućnost. ${ }^{40}$

${ }^{34}$ JAREB, Sovjetski zločin u Katynskoj šumi, 157.

35 Isto, 159, 162-163.

36 Eduard Miloslavić rođen je 1884. u Oaklandu u obitelji hrvatskih iseljenika iz Dubrovnika, a umro je 1952. u SAD-u. Sudjelovanje u Drugom balkanskom i Prvom svjetskom ratu predodredilo je da se specijalizira na području sudske medicine, gdje će ostvariti zapažen međunarodni uspjeh. Osobito važno mjesto u njegovu profesionalnom životu ima sudjelovanje u međunarodnoj komisiji koja je istraživala zločine u Katynskoj šumi. Vidi: „Miloslavić, Eduard"; JAREB, Sovjetski zločin u Katynskoj šumi, 157-159.

${ }_{37}$ Šalata je kvart u Zagrebu. Nalazi se istočno od Kaptola i Trga bana Josipa Jelačića, odnosno sjeverno od Vlaške ulice. Uz Medicinski fakultet, ondje se nalaze i kulturno-obrazovni i sportski sadržaji poput Športsko rekreacijskog centra „Šalata”, Nadbiskupske klasične gimnazije i dr.

38 Financijski izvori za izgradnju i opremanje Medicinskoga fakulteta bili su podijeljeni u tri osnovne skupine: imovina sveučilišne zaklade za medicinski fakultet, imovina zaklade stradajućih u ratu i dio imovine komasirane za dobrotvorne svrhe. Međutim, uslijed poslijeratne inflacije dotadašnji novčani iznos bio je znatno smanjen. Stoga je fakultet već 1920. bio u velikim problemima, koji će djelomično biti riješeni financijskom pomoći koju je osigurao ekonomist Edo Marković. „Izgradnja Medicinskog fakulteta”, Alma mater Croatica (Zagreb), 1 (1937), br. 3, 81-93; „Gradnja zgrada za medicinski fakultet”, Jutarnji list (Zagreb), 12. 5. 1918., 2.

39 PEĆINA, KLARICA, Medicinski fakultet Sveučilišta u Zagrebu, 33-48; ZIMOLO et al., Prvih 85 godina, 1-8.

40 HR-UNIZG-OS, DEKANATU LIJEČNIČKOG FAKULTETA SVEUČILIŠTA KRALJEVINE SRBA, HRVATA I SLOVENACA U ZAGREBU, Broj: 1363, Predmet: Medicinski fakultet, pitanje IX. semestra, Na broj 24.349 od 14. srpnja 1922. 
Usprkos svim problemima, nastava iz sudske medicine na Medicinskom fakultetu počela se održavati akademske godine 1922./1923. S obzirom na to da se sudska medicina na Sveučilištu u Zagrebu slušala i prije osnutka Medicinskoga fakulteta, teorijski dio nastave preuzeo je Ernest Miler, profesor s Pravnoga fakulteta. Medicinski dio u početku je izvodilo više osoba. ${ }^{41}$ Tako je akademske godine 1922./1923. dio nastave držao kirurg Teodor Wickerhauser. ${ }^{42}$ Sljedeće je godine dio nastave držao i ginekolog Franjo Durst. ${ }^{43}$ Međutim, najveći dio nastave na sebe je preuzeo Jurak. Nastavu iz sudske medicine počeo je izvoditi u ljetnom semestru akademske godine 1922./1923. ${ }^{44}$ Njegov će položaj konačno biti trajno utvrđen na sjednici fakulteta održanoj 26. travnja 1924. godine. Tada je određeno da u nemogućnosti pronalaska odgovarajućega profesora za sudsku medicinu Miler i Jurak nastave držati nastavu. ${ }^{45}$ Nakon Milerove smrti 1928. svu nastavu na sebe je preuzeo Jurak, a tako će ostati do Miloslavićeva dolaska 1932. godine.

Jurak je u prosincu 1923. bio imenovan i ispitivačem sudske medicine na trećem strogom ispitu. ${ }^{46}$ Iako se nastava počela izvoditi od akademske godine 1922./1923., ispiti su se držali i prije toga. Radilo se o pristupnicima koji su se prebacivali na studij medicine u Zagreb, pa su ispit iz sudske medicine morali polagati kao razlikovni predmet. U pismohrani Medicinskoga fakulteta prvi takav sačuvani ispitni list nosi datum 21. kolovoza 1920. godine. Radi se o ispitnom listu neurologa Stjepana Poljaka, koji je toga dana polagao ispit iz sudske medicine i farmakologije. ${ }^{47} \mathrm{Oba}$ je ispita položio s odličnim, a ispit iz

${ }^{41}$ BAZALA, Poviestni razvoj medicine u hrvatskim zemljama, 168; „Iz Medicinskog fakulteta u Zagrebu”, Staleški glasnik: prilog Liječničkog vjesnika (Zagreb), 46 (1924), br. 1, 17, pristup ostvaren 2. 1. 2021., http://library.foi.hr/m3/casview.aspx?fl=t7\&sql=SDCCD2YC924YDDDDC-DDD-SSDDC7.

${ }^{42}$ HR-MEF-OS, POKRAJINSKOJ UPRAVI ZA HRVATSKU I SLAVONIJU, ODJELJENJE ZA PROSVJETU I VJERU, Broj: 44.821/1923., Predmet: Miler Ernst, Dr. kr. jav. red. profesor, Zagreb, predavanje iz sudske medicine u liječničkom fakultetu kraljevskog sveučilišta Srba, Hrvata i Slovenaca u Zagrebu.

43 HR-MEF, 1923., Franjo Durst - sudska medicina; „Iz Medicinskog fakulteta u Zagrebu”, Staleški glasnik: prilog Liječničkog vjesnika, 45 (1923), br. 12, 241, pristup ostvaren 2. 1. 2021. http://library.foi.hr/m3/casview.aspx?fl=t9\&sql=SDCCD2YC923YDDDC2-DDD-SSD24C.

${ }^{44}$ HR-MEF-OS, POKRAJINSKOJ UPRAVI ZA HRVATSKU I SLAVONIJU, ODJELJENJE ZA PROSVJETU I VJERU, Broj: 18.507.-/1923., Gospodinu dr. Ljudevitu Juraku, kraljevskom javnom redovitom profesoru veterinarske visoke škole u Zagrebu.

45 HR-MEF-OS, Broj: 697/1924., Predmet: sudska medicina predavanje u ljetnom poljeću $1923 / 24$.

${ }^{46}$ HR-MEF-OS, POKRAJINSKOJ UPRAVI ZA HRVATSKU I SLAVONIJU, ODJELJENJE ZA PROSVJETU I VJERU, Broj: 48.347./1923., Predmet: Jurak Ljudevit Dr. profesor kr. veterinarske visoke škole, Imenovanje ispitivačem za sudsku medicinu u liječničkom fakultetu Zagreb.

47 Poljak je ostvario veliki uspjeh na području neurologije radeći u SAD-u. KLÜVER, „Dr. Stephen Polyak”, 306; „Poljak, Stjepan”. 
sudske medicine držao mu je kirurg Julije Budisavljević. ${ }^{48}$ Ispite su uz Juraka i Budisavljevića držali i Miler i Saltykow. ${ }^{49}$

Može se reći da su prva desetljeća održavanja nastave iz sudske medicine na Medicinskom fakultetu obilježena improvizacijom. Iako su Miler i Jurak imali središnju ulogu kao nositelji nastavne aktivnosti, iz dostupne literature i arhivske građe vidljiv je doprinos i drugih profesora. Situacija će se bitno popraviti dolaskom Miloslavića i osnivanjem Zavoda za sudsku medicinu i kriminalistiku.

\section{Dolazak Eduarda Miloslavića i osnutak Zavoda}

Osnutak Zavoda za sudsku medicinu i kriminalistiku označio je novu etapu u razvoju sudske medicine na prostoru Hrvatske. Osnivač Zavoda i njegov prvi predstojnik bio je Eduard Miloslavić. Miloslavić je odlaskom u SAD ostvario svjetsku karijeru na području sudske medicine. No, unatoč višegodišnjem boravku u SAD-u, svoje veze s Hrvatskom nije prekidao.

O Miloslavićevu dolasku u Zagreb početkom 30-ih godina među ostalima je pisao i Jareb. On kaže da je Miloslavić u pismu upućenom farmakologu Miroslavu Mikuličiću u listopadu 1930. rekao da ima želju vratiti se u Hrvatsku, gdje bi mogao preuzeti katedru sudske medicine na Medicinskom fakultetu u Zagrebu. ${ }^{50}$ Međutim, dokumentacija koja se fragmentarno sačuvala u arhivi fakulteta upućuje na to da su Miloslavić i Mikuličić komunicirali i prije toga.

Najraniji dokazi komunikacije između Mikuličića i Miloslavića mogu se smjestiti u prve godine 1920-ih. U to je vrijeme Mikuličić kao predstojnik Zavoda za opću i eksperimentalnu patologiju i farmakologiju započeo niz akcija za prikupljanje novčanih sredstava potrebnih za izgradnju i opremanje Medicinskoga fakulteta. ${ }^{51}$ Mikuličiću je tada dobro došlo poznanstvo s Miloslavićem jer mu je on bio jedna od veza s tadašnjim iseljeništvom u SAD-u. Naime, Miloslavić je u to doba bio aktivno uključen u rad Hrvatske bratske zajednice i Hrvatskoga radiše. ${ }^{52} \mathrm{~S}$ obzirom na to da je dio sredstava tim akcijama uistinu bio sakupljen, može se pretpostaviti da su uspjeli uspostaviti dobru suradnju i

48 HR-MEF-OS, Dekanatu liječničkog fakulteta sveučilišta u Zagrebu, Broj 1989, Prim. 21. VIII. 1920., Zapisnik ispita iz farmakologije i sudske medicine.

49 Primjerice, Saltykow je 14. veljače 1923. održao ispit iz sudske medicine prvom diplomiranom liječniku na MEF-u, Zlatku Sremcu. ČEČUK, BELICZA, ŠKRBIĆ, Medicinski fakultet Sveučilišta u Zagrebu, 474.

50 JAREB, Sovjetski zločin u Katynskoj šumi, 166.

51 Tadašnji dekan Dragutin Mašek 23. siječnja 1923. uputio je molbu Mikuličiću da započne s akcijom prikupljanja sredstava za izgradnju fakulteta među hrvatskom emigracijom. Mikuličić je i prije organizirao različite akcije među hrvatskim iseljeništvom, a prikupljena sredstva omogućila su mu nabavku raznih aparata poput rendgena. HR-MEF-OS, Broj: 53/1923., Dekanatu liječničkog fakulteta u ZAGREBU; HR-MEF-OS, Broj: 215/extern., Predmet: provođenje organizovane akcije za podignuće ovdašnjeg sveučilišta Josipa Jurja Strossmayera u tuđini (Americi); Sveučilište Kraljevine Srba, Hrvata i Slovenaca u Zagrebu, 127.

52 JAREB, Sovjetski zločin u Katynskoj šumi, 167. 
očuvati prijateljske veze koje su postojale i prije Miloslavićeva odlaska u SAD. U prilog tome idu i događaji iz 1930. godine. Mikuličić je u listopadu te godine upozoravao dekanat na važnost izbora kvalitetnoga nastavničkoga kadra, ističući pritom „da mi gubimo, čak i po svema svida puštamo bolje i najbolje ljude, da svoj rad tudjini posvećuju, dok se kod nas preka potreba za ovakvim ljudima sve šta je dalje u bitisanju i razvitku fakulteta, sve to imperativnije ukazuje". ${ }^{53}$ Vođen tom mišlju, predlaže da se za profesora sudske medicine razmotri Miloslavića. Usto je Mikuličić priložio i prijepis pisma iz komunikacije s Miloslavićem. ${ }^{54}$ Stoga se može zaključiti da je upravo Mikuličić bio jedan od važnijih posrednika u Miloslavićevu povratku u Hrvatsku. Međutim, vjerojatno nije bio jedina veza. Karlo Radoničić, tadašnji dekan Medicinskoga fakulteta, u svojem pismu upućenom Miloslaviću ističe da „time nije rečeno, da je vaša stvar propala, jer ne dvojim, da imadete jake zagovaratelje, na jednom mjerodavnom mjestu, to jest kod vlade". ${ }^{55}$ Nažalost, Radoničić u pismu nije rekao na koga točno iz vlade misli, pa je teško reći o kojoj se osobi radi. Osim toga Radoničić je u pismu objašnjavao Miloslaviću da fakultet ne može osigurati stambeni prostor u kojemu bi ovaj mogao stanovati kad preuzme mjesto profesora sudske medicine. ${ }^{56}$ No istaknuo je da to ne znači da je cijela stvar oko njegova namještenja propala.

Cijeli će se postupak ubrzati 16. prosinca 1931., kad je imenovana komisija koja je trebala napraviti prijedlog za popunjavanje katedre sudske medicine. ${ }^{57}$ Ubrzo nakon toga, na sjednici vijeća Medicinskoga fakulteta 16. siječnja 1932. odlučeno je da sudska medicina postane obvezni predmet. Na kraju je 15. prosinca 1932. donesen ukaz kojim je Miloslavić određen za profesora sudske medicine u Zagrebu. ${ }^{58}$ Miloslavić je 3. studenog 1933. održao nastupno

53 HR-MEF-OS, INSTITUT ZA OPĆU EXP. PATOLOGIJU (patološku fiziologiju) I FARMAKOLOGIJU KR. SVEUČILIŠTA U ZAGREBU, Prot. broj 440/dek., Predmet: Razvitak fakulteta quood personam.

54 HR-MEF-OS, INSTITUT ZA OPĆU EKSPERIMENTALNU PATOLOGIJU I FARMAKOLOGIJU SVEUČILIŠTA U ZAGREBU, 2166/30, Predmet: Razvitak fakulteta quood personam!

55 HR-MEF-OS, INSTITUT ZA OPĆU EKSPERIMENTALNU PATOLOGIJU I FARMAKOLOGIJU SVEUČILIŠTA U ZAGREBU, Prot. broj: 347/dek., P.T. DEKANATU MEDICINSKOG FAKULTETA U ZAGREBU.

56 U to je doba na Medicinskom fakultetu bilo uobičajeno da njegovi zaposlenici ondje i žive. To je vrijedilo za sve skupine, od pomoćnih djelatnika do profesora. Osobito je zanimljiv primjer pročelnika Zavoda za farmakologiju Miroslava Mikuličića, koji se često sukobljavao s upravom fakulteta jer je zahtijevao bolji smještaj. HR-MEF-OS, Institut za opću exp. patologiju i farmakologiju Kr. sveučilišta u Zagrebu, 4/VII. 1921., P.T. Profesorskom zboru med. fak. i povjereništvu prosvjete u Zagrebu. Na različitim zavodima fakulteta živjeli su alergolog i dermatovenerolog Franjo Kogoj, anatom Drago Perović, bakteriolog Emil Prašek, biolog Boris Zarnik i drugi. HR-MEF-OS, Broj: 874/1932., Predmet: Izvješće o stanovima u fakultetskim zgradama.

57 HR-MEF-OS, Broj: 1827/1932., Predmet: Izvještaj o radu medicinskog fakulteta, te o veličini i utrošku naplata za nabavku materijala - REKTORATU UNIVERZITETA u Zagrebu.

58 HR-MEF-OS, INSTITUT ZA OPĆU EKSPERIMENTALNU PATOLOGIJU I FARMAKOLOGIJU SVEUČILIŠTA U ZAGREBU, Prot. Broj: 492/dek., Predmet: Imenovanje prof. 
predavanje pod nazivom Moderni razvitak sudske medicine. Stvaranje nove znanstvene grane - kriminalne patologije. ${ }^{59}$

Iako je Miloslavić imenovan za profesora krajem 1932., još je trebalo pričekati da se pokrene i Zavod za sudsku medicinu i kriminalistiku. To se ostvarilo tijekom 1933. godine. U izvještaju o radu za 1933./1934. stoji da je Zavod osnovan rješenjem Ministarstva prosvjete Kraljevine Jugoslavije 8. rujna 1933., a u zimskom semestru 1933. počeo je s postupnim radom. ${ }^{60}$ Treba reći da se u literaturi navodi da je Zavod osnovan 7. lipnja 1935. odlukom Vijeća Medicinskoga fakulteta, no nije navedeno na koji se dokument pritom poziva. ${ }^{61}$ Smatram da je 8 . rujna 1933. vjerodostojniji zbog tri razloga. Prvi i osnovni jest taj što u izvješću za akademsku godinu 1933./1934. to ističe sâm Miloslavić. Osim toga Zavod je od 1933. do 1935. djelovao u Zavodu za histologiju i embriologiju, o čemu svjedoči i sačuvana dokumentacija. Na kraju, po pokretanju Zavoda razvila se rasprava o sudskomedicinskim obdukcijama, koje ne bi bilo da Zavod nije osnovan i da na njemu 1934. nije izvedena prva obdukcija. Međutim, može se pretpostaviti da je 1935. protumačena kao godina osnutka s obzirom na to da se Zavod tada smjestio u prostorije u kojima je i danas.

Zavod za sudsku medicinu i kriminalistiku rad je započeo u prostorijama Zavoda za histologiju i embriologiju, koji je tada vodio Boris Zarnik. Međutim, to se rješenje nije pokazalo odgovarajućim. Rad u Zavodu bio je čista improvizacija. Cjelokupna zavodska djelatnost trebala se razvijati u četiri prostorije koje Zarnik tada nije koristio, što dugoročno nije mogla biti opcija. Osim toga teška financijska situacija bitno je utjecala na ozbiljniju organizaciju Zavoda. Stoga je Miloslavić u predstavci upućenoj Ministarstvu prosvjete 1934. istaknuo da je loša financijska situacija dovela do toga da je „[Zavod] dosad najslabije smješten i dotiran, jer raspolaže u svemu sa četiri sobe, polovicom uzete iz nastavničkog stana i polovicom od morfološko-biološkog instituta. Nema dvorane za seciranje, nema spremišta za lješeve ni čitav niz specijalnih laboratorija i prostorija za sudsko-medicinski muzej”. ${ }^{62}$ Kako gradnja nove zgrade za potrebe Zavoda nije bila moguća, Miloslavić je predložio da mu se

dr. E. Miloslavića red. prof. sudske medicine ukazom od dne 15./XII.1932., P.T. DEKANATU MEDICINSKOG FAKULTETA u Zagrebu.

59 DUGAČKI, „Eduard Miloslavić, Zmaj od svete Mandaljene”, 15.

60 Zavod za sudsku medicinu i kriminalistiku tada se zvao Institut za sudsku medicinu. Godine 1938. preimenovan je u Institut za sudsku medicinu i kriminalistiku. HR-MEF-OS, INSTITUT ZA SUDSKU MEDICINU medicinskog fakulteta univerziteta KRALJEVINE JUGOSLAVIJE U ZAGREBU, Izvještaj o radu instituta za sudsku medicinu u godini 1933/34.; ČEČUK, BELICZA, ŠKRBIĆ, Medicinski fakultet Sveučilišta u Zagrebu, 475.

${ }_{61}$ Prvi spomen ovoga u literaturi pronašao sam u monografiji Medicinskoga fakulteta objavljenoj 1984. godine. Tamo stoji da je Zavod pokrenut odlukom Vijeća Medicinskoga fakulteta 7. lipnja 1935. Međutim, nije navedeno na što se autor te tvrdnje poziva, a tijekom istraživanja nisam pronašao nijedan dokument koji bi me upućivao na navedeni datum. ČEČUK, BELICZA, ŠKRBIĆ, Medicinski fakultet Sveučilišta u Zagrebu, 475.

${ }^{62}$ HR-MEF-OS, Broj: 2561/1934., Predmet: Konačna izgradnja medicinskog fakulteta u Zagrebu. 
dodijeli između 800.000 i 900.000 dinara da bi izveo barem nužnu adaptaciju postojećih prostorija. Pritom je istaknuto da je Zavodu dotad dodijeljeno tek 80.000 dinara. U izvješću za 1933./1934. Miloslavić je isticao da „je institut za sudsku medicinu morao iz tih malenih prihoda nabaviti ne samo potrebni laboratorijski i ini namještaj, znanstvenu aparaturu itd., nego i da podmiruje svakidašnji sitne potrebe instituta" ${ }^{63}$

Uz organizaciju novoosnovanoga Zavoda trebalo je riješiti i pitanje nadležnosti nad sudskomedicinskim obdukcijama. Oko toga će izbiti problem jer je Ministarstvo unutrašnjih poslova odlučilo da se sve sudskomedicinske obdukcije obavljaju na novoosnovanom Zavodu. No ta je odluka izazvala Jurakovo negodovanje jer je on dotad izvodio veći dio toga posla u sklopu Prosekture. Jurak je isticao da novoosnovani Zavod nema kadar koji bi mogao pokriti sve potrebe ne samo sudskih okruga u Zagrebu i Savskoj banovini nego i u susjednim banovinama. Usto je naglasio da je ta odluka donesena bez ikakve obavijesti, što je onemogućilo da se pravovaljano reorganizira rad Prosekture. ${ }^{64}$ Novim zakonom ukinuta je i naknada za takve poslove, za što je Jurak smatrao da je izravan udarac na radnička prava liječnika jer su ostali bez prihoda na koje su dotad imali pravo. ${ }^{65}$ Sporni je zakon donesen s ciljem centralizacije sudskomedicinske aktivnosti na prostoru grada Zagreba i okolice. Ta se odluka opravdavala time da je to potpuno normalna praksa u Beogradu i svim ostalim europskim državama. ${ }^{66}$ Usto država više nije bila dužna plaćati sudskomedicinske obdukcije Prosekturi, što je dovelo do uštede jer je Zavodu to bio primarni posao koji su obavljali za to plaćeni djelatnici. Naravno, ta odluka nije odgovarala upravi Medicinskoga fakulteta, koja je time izgubila dio prihoda na koje je dotad računala. ${ }^{67}$ No to se nije promijenilo, a prva će obdukcija na Zavodu biti izvedena 16. travnja $1934 .{ }^{68}$

Može se reći da je uređenjem nadležnosti nad sudskomedicinskim obdukcijama proces osnivanja Zavoda za sudsku medicinu i kriminalistiku završen. Unatoč manjku financija i nedostatku odgovarajućih prostorija, Zavod je profunkcionirao. Nova faza u razvoju Zavoda nastupila je premještanjem u dio prostorija Zavoda za opću i eksperimentalnu patologiju i farmakologiju.

${ }^{63}$ HR-MEF-OS, INSTITUT ZA SUDSKU MEDICINU medicinskog fakulteta univerziteta KRALJEVINE JUGOSLAVIJE U ZAGREBU, Izvještaj o radu instituta za sudsku medicinu u godini 1933/34.

64 Jurak ističe da je u Prosekturi od 1914. do 1934. napravio više stotina sudskomedicinskih analiza. HR-MEF-OS, Broj 863/1934., SAVJETU MEDICINSKOG FAKULTETA UNIVERZITETA U ZAGREBU.

${ }^{65}$ HR-MEF-OS, Broj 863/1934., SAVJETU MEDICINSKOG FAKULTETA UNIVERZITETA U ZAGREBU.

66 HR-MEF-OS, MINISTARSTVO PRAVDE, Br. 23099, 18. marta 1934. godine, Beograd.

${ }_{67}$ HR-MEF-OS, Broj 863/1934., Zagreb, 27. aprila 1934., Vrlo poštovani gospodine profesore!

68 ČEČUK, BELICZA, ŠKRBIĆ, Medicinski fakultet Sveučilišta u Zagrebu, 475. 


\section{Zavod za sudsku medicinu i kriminalistiku od 1935. do 1945.}

Ključni događaj za povijest Zavoda za sudsku medicinu i kriminalistiku dogodio se 1935., kad je preseljen u nove prostorije, gdje se nalazi i danas. Po osnutku Zavoda bilo je jasno da prostorije na Zavodu za histologiju i embriologiju mogu poslužiti samo kao privremeno rješenje. $S$ obzirom na to da je Zavod za opću i eksperimentalnu patologiju i farmakologiju u to doba prolazio razdoblje krize i gotovo bio ugašen, on se pokazao idealnim za smještanje Zavoda za sudsku medicinu i kriminalistiku. ${ }^{69}$ To je razdoblje važno i zbog toga što će se unatoč svim poteškoćama razviti jezgra znanstveno-nastavne aktivnosti na temelju koje će se Zavod razvijati i u sljedećim desetljećima.

Paralelno s Miloslavićevim povratkom u Zagreb došla je do vrhunca kriza na Zavodu za opću i eksperimentalnu patologiju i farmakologiju. Tadašnji predstojnik Zavoda Miroslav Mikuličić razišao se s upravom fakulteta i većim dijelom zaposlenika. Stoga je privremenu upravu nad Zavodom preuzeo fiziolog Fran Smetanka, čiji je glavni zadatak bio reorganizirati Zavod. S obzirom na tešku financijsku situaciju i dugove koji su ostali iza Mikuličićeve uprave, glavni Smetankin posao bio je provesti financijsku stabilizaciju. ${ }^{70}$ Rasprodajom nepotrebnih uređaja, gašenjem pojedinih laboratorija i raspoređivanjem viška djelatnika na druge sastavnice Medicinskoga fakulteta Smetanka je oslobodio dio prostornih kapaciteta. K tome se Mikuličićevim odlaskom oslobodio i gotovo čitav kat zavodske zgrade na kojemu je stanovao s obitelji. Takav razvoj situacije otvorio je mogućnost da se u te prostorije smjesti Zavod za sudsku medicinu i kriminalistiku, što se na kraju i dogodilo. Dogovor je sklopljen 26. lipnja 1935., a pregovaralo se na temelju nacrta objavljenog u Spomenici Akademičkog senata iz 1924. godine. ${ }^{71}$ Konačna odluka o preseljenju Zavoda za sudsku medicinu i kriminalistiku u prostorije Zavoda za farmakologiju donesena je 6. kolovoza $1935 .^{72}$ Tim su dogovorom Zavodu za sudsku medicinu i kriminalistiku pripale prostorije u podrumu i prizemlju, kao i nekadašnji Mikuličićev stan na prvom katu. ${ }^{73}$ Usto su prenamijenjeni zatečeni laboratoriji i uređaji. Laboratorij za kemijsku analizu prenamijenjen je za forenzično-kemijska istraživanja. Mikrofotografija se pak iskoristila za snimanje nalaza forenzičnih pretraga. Dogovoreno je i da će se mikrofotografija modernizirati, a pravo na njezino korištenje trebali su imati i djelatnici, sada preimenovanog, Zavoda za farmakologiju. Predavaonica je

69 Danas je naziv te ustanove Zavod za farmakologiju. Iz njega će se 1950. razviti i Zavod za patofiziologiju. U sklopu prvotnoga Zavoda za opću i eksperimentalnu patologiju i farmakologiju odvijala se znanstveno-nastavna djelatnost dviju medicinskih grana, patofiziologije i farmakologije.

70 PEĆINA, KLARICA, Medicinski fakultet Sveučilišta u Zagrebu, 498-499.

71 HR-MEF-OS, Institut za sudsku medicinu medicinskog fakulteta Univerziteta Kraljevine Jugoslavije u Zagrebu, Broj: 208/35., SAVJETU MEDICINSKOG FAKULTETA U ZAGREBU.

72 ČEČUK, BELICZA, ŠKRBIĆ, Medicinski fakultet Sveučilišta u Zagrebu, 475.

73 HR-MEF-OS, Institut za sudsku medicinu medicinskog fakulteta Univerziteta Kraljevine Jugoslavije u Zagrebu, Broj: 208/35., SAVJETU MEDICINSKOG FAKULTETA U ZAGREBU. 
ostala u ingerenciji reorganiziranoga Zavoda za farmakologiju. Svi uređaji koji su se dotad koristili za potrebe patofiziologije bili su prebačeni u inventar Zavoda za sudsku medicinu i kriminalistiku, ${ }^{74}$ kojem su tim potezom osigurane prijeko potrebne prostorije za daljnji razvoj. No problemi time nisu bili potpuno riješeni.

Financijska nestabilnost i dalje je bila problem te bitno otežavala razvoj cjelokupnoga fakulteta. Tako je u proračunu za 1936./1937. bilo predviđeno da se za građevinske radove oko Medicinskoga fakulteta u Zagrebu izdvoji 2.750.000 dinara. Međutim, zbog teške financijske situacije u državi taj je iznos srezan na 952.000 dinara. Posljedično je Zavodu za sudsku medicinu i kriminalistiku na kraju pripalo 50.000 dinara, što nije bilo dovoljno za cjelovitu adaptaciju prostorija koje su mu dodijeljene nakon 1935 . godine. ${ }^{75}$ Slično je bilo i poslije. Miloslavić je u dopisu iz 1939. zaključio da je Zavod od obećane dotacije u iznosu od 430.000 dinara od uprave dobio tek 5.000 dinara. Taj je iznos bio nedostatan za bilo kakva ozbiljnija ulaganja. Primjerice, 1939. u zavodskom muzeju još uvijek nisu postojali odgovarajući ormari za preparate. Stoga je Miloslavić predložio da se podigne kredit koji bi pokrio troškove nabavke šest željeznih ormara u iznosu od 52.000 dinara. ${ }^{76}$ Osim toga, širenje znanstveno-nastavne djelatnosti dovelo je do toga da su raspoloživi prostorni kapaciteti postali premaleni za potrebe Zavoda.

Da bi riješio te probleme, Miloslavić je 1940. iznio nekoliko prijedloga, koji većim dijelom nikad nisu realizirani, što zbog manjka novca, što zbog rata. Unatoč tome zanimljivi su jer svjedoče o tadašnjoj situaciji na Zavodu. Miloslavić je u prijedlogu, među ostalim, iznio da se na Zavodu 1935. izvodilo 160 obdukcija, a 1940. taj se broj popeo na preko 400; broj slušača narastao je sa 70 (1935.) na 144 (1940.). Suočen s time, svoj je prijedlog podijelio u 12 točaka, odnosno zahtjeva. Prvi zahtjev bio je veći laboratorij da bi se moglo poučavati više studenata odjednom jer u postojeći stane tek njih osam. Drugi je bio da se za studentske vježbe osiguraju dvije prostorije, jedna za mikroskopiranje i jedna za presvlačenje (garderoba). Treći zahtjev bio je izgradnja prostorije za identifikaciju pokojnika. U četvrtoj točki Miloslavić je naveo da treba napraviti dovoljno veliku prostoriju za čuvanje dokaza. Peti zahtjev predviđao je osiguravanje prostorije za čuvanje povjerljivih spisa i ostale dokumentacije koja se zbog policijskih istraga mora strogo čuvati. U šestoj točki istaknuo je prijeku potrebu za prostorijom u kojoj bi se obavljala sudbeno-klinička aktivnost. U sedmom zahtjevu istaknuta je potreba proširenja skladišnoga prostora. Osma točka dotaknula se pitanja kupaonice. Naime, u Zavodu nije postojala kupaonica gdje bi se zaposlenici mogli oprati nakon rada s rizičnim leševima, poput onih zaraženih virusima i slično. To je predstavljalo

74 Isto.

75 Godišnjak Hrvatskoga sveučilišta u Zagrebu za školske godine 1933/34-1938/39., 298.

76 HR-MEF-OS, INSTITUT ZA SUDSKU MEDICINU I KRIMINALISTIKU UNIVERZITETA KR. JUGOSLAVIJE U ZAGREBU, Broj: 283/1939., DEKANATU MEDICINSKOG FAKULTETA Zagreb. 
potencijalnu opasnost od izbijanja zaraze, što bi se negativno odrazilo na rad Zavoda za sudsku medicinu, a moglo je ugroziti i rad ostalih zavoda i katedri kao i građane koji su živjeli na Šalati. Miloslavić je istaknuo i potrebu za maceracijom, gdje bi se izrađivali preparati, te za prostorijama za uzgoj pokusnih životinja. U jedanaestom zahtjevu istaknuta je potreba gradnje garaže za mrtvački automobil. Na kraju Miloslavić govori o potrebi za stambenim prostorom u kojemu bi stanovali zaposlenici jer je Zavod tada imao samo tri mala mansardna stana. Zato je predložio da se na zapadnoj strani zgrade Zavoda nadogradi krilo u koje bi se mogle smjestiti sve potrebne prostorije. Također je istaknuo da je to jedino rješenje s obzirom na to da se odustalo od nadogradnje Zavoda za patologiju, kamo bi se smjestila sudska medicina. ${ }^{77}$

Unatoč svim problemima Zavod je od 1935. do 1945. bitno napredovao u znanstvenom smislu. Tako je 1934./1935. nabavljena sljedeća oprema: različiti mikrotomi, projektor, aparat za uklapanje histoloških preparata u parafin, usporedni mikroskop za kriminalne svrhe, fotoaparat i kolorimetar. ${ }^{78}$ Sljedeće godine nabavljeni su i mikroskopski objektiv, ultra-pak aparat te uređaj za mjerenje padanja broja krvnih zrnaca s priborom. ${ }^{79}$ Iste su godine nabavljeni i hladnjaci za mrtvačnicu, što je bilo dotad najskuplje ulaganje u zavodsku opremu. ${ }^{80}$ Usprkos poteškoćama Zavod je, ovisno o mogućnostima, i dalje opreman. Tako je 1941. nabavljen rendgen i pet ormara za potrebe Muzeja, o kojemu je tada brigu vodila Anka Tomičić Budak. ${ }^{81}$ Priliku da širu javnost upoznaju sa znanstvenom aktivnošću zaposlenici Zavoda dobili su u studenom 1942. u sklopu izložbe Jedna godina rada u Nezavisnoj Državi Hrvatskoj, koja se održala u prostorima Zagrebačkoga zbora. Tom su prilikom zavodski djelatnici izložili svoja dotadašnja postignuća i važnije uređaje. ${ }^{82} \mathrm{Za}$ tu su svrhu bili predstavljeni i netom nabavljeni uređaji. Svakako najvažniji novitet bio je univerzalni spektrograf za vidljivo i ultraljubičasto svjetlo s priborom za emisijski i apsorpcijski spektar. Nabavljeno je i deset mikroskopa, dodatni uređaj za spektrografsku analizu, 700 muzejskih stakala za preparate i dr. ${ }^{83}$

77 Ovdje do izražaja dolazi ideja da se u sklopu zgrade Zavoda za patologiju osnuje i Zavod za sudsku medicinu i kriminalistiku, no to na kraju ipak nije zaživjelo. HR-MEF-OS, INSTITUT ZA SUDSKU MEDICINU I KRIMINALISTIKU UNIVERZITETA KR. JUGOSLAVIJE U ZAGREBU, Broj: 1019/1940., Predmet: Nadogradnja jednog krila za Institut za sudsku medicinu i kriminalistiku, DEKANATU MEDICINSKOG FAKULTETA Zagreb.

78 HR-MEF-OS, INSTITUT ZA SUDSKU MEDICINU I KRIMINALISTIKU UNIVERZITETA KR. JUGOSLAVIJE U ZAGREBU, Broj: 206/35., Predmet: Izvještaj o radu fakulteta u godini 1934/1935.

79 HR-MEF, Izvještaj o radu Instituta za sudsku medicinu i kriminalistiku.

80 HR-MEF, Protokol kouladovanja Za posao dobava i montaža hladioničkog uredjaja u Institutu za sudsku medicinu, medicinskog fakulteta u Zagrebu, Sastavljen dana 11. jula 1936. godine, broj 24675/36.

${ }^{81}$ HR-MEF-OS, INSTITUT ZA SUDSKU MEDICINU I KRIMINALISTIKU UNIVERZITETA KR. JUGOSLAVIJE U ZAGREBU, Broj: 840/1941., DEKANATU MEDICINSKOG FAKULTETA Zagreb.

82 HR-MEF-OS, Broj: 2922 - 1942., Predmet: Izvještaj o radu medicinskog fakulteta $\mathrm{Hr}$ vatskog sveučilišta u školskoj godini 1941./1942.

83 HR-MEF-OS, Broj: 1136/1942., DEKANATU MEDICINSKOG FAKULTETA, Zagreb. 
Paralelno s opremanjem Zavoda razvijala se i laboratorijska djelatnost. Histološki laboratorij osnovan je prilikom pokretanja Zavoda. Toksikološki laboratorij počinje s djelatnošću 1941. dolaskom Nikole Novakovića, a hematološki laboratorij proradio je 1945. godine. ${ }^{84}$

Razvijala se i nastavna aktivnost. U izvješću za 1934./1935. navodi se da se nastava izvodila u dva semestra. Radi kvalitetnijega prijenosa znanja sekcije su se izvodile u grupama do deset studenata. Sekcije su bile osmišljene tako da bi na njima svaki put jedan do dva studenta bila aktivno uključena u njihovo izvođenje, uz prisutnost asistenta i predstojnika. ${ }^{85}$ Uredbom medicinskih fakulteta sa svim saveznim propisima iz 1937. bilo je određeno da se na katedri za sudsku medicinu i kriminalistiku predaju dva kolegija. Sudska medicina bila je obvezni kolegij, a kriminalistika izborni. ${ }^{86}$ No tijekom 1938. i 1939. predlagala se nova organizacija nastave iz sudske medicine, prema kojoj bi se u XI. semestru dva sata tjedno držala predavanja i dva sata vježbe. U XII. semestru četiri sata tjedno držala bi se predavanja i dva sata vježbe. ${ }^{87}$ Unatoč tim prijedlozima nastava se uza sve promjene uvijek držala u dva semestra. Zanimljivo je primijetiti i da su studenti bili aktivno uključeni u praktične aktivnosti. Tako su se akademske godine 1940./1941. sudskomedicinske i kriminalističke vježbe održavale dva puta tjedno po dva sata. Studenti su na vježbama u suradnji s asistentima radili pretrage iz sudske hematologije, pretrage dlaka i sperme, određivali krvne grupe za utvrđivanje očinstva, radili spektroskopske analize te razne mikroskopske pretrage tkiva. ${ }^{88}$ Ta se praksa odvijala i tijekom rata iako je to bio veliki organizacijski izazov. Naime, akademske godine 1943./1944. na Zavodu su radila četiri asistenta: Alojzije Maly, Zvonimir Kušević, Zvonimir Milković i Nikola Novaković. No te je godine u nastavi sudjelovao samo Maly jer su ostala trojica bila ratni obveznici. ${ }^{89}$ Tako je Maly te godine održavao vježbe u grupama od 10 do 15 studenata, s time da je sudsku medicinu tada u generaciji slušalo 135 studenata, što je bilo veliko nastavno opterećenje za jednoga asistenta.

Bitne promjene na Zavodu događaju se i na kraju promatranoga perioda te označavaju početak novoga razdoblja. Privremenu upravu nad Zavodom 1944. preuzima patolog Zvonimir Kopač, a 1945. na čelo Zavoda dolazi Ante

84 ČEČUK, BELICZA, ŠKRBIĆ, Medicinski fakultet Sveučilišta u Zagrebu, 475.

85 HR-MEF-OS, INSTITUT ZA SUDSKU MEDICINU I KRIMINALISTIKU UNIVERZITETA KR. JUGOSLAVIJE U ZAGREBU, Broj: 206/35., Predmet: Izvještaj o radu fakulteta u godini 1934/1935.

86 Uredba medicinskih fakulteta, 7-8.

87 „Misli o nastavi, naročito o sveučilišnoj”, Alma mater Croatica, 4 (1941), br. 7, 260.

${ }_{88}$ HR-MEF-OS, INSTITUT ZA SUDSKU MEDICINU I KRIMINALISTIKU UNIVERZITETA KR. JUGOSLAVIJE U ZAGREBU, Broj: 840/1941., DEKANATU MEDICINSKOG FAKULTETA Zagreb.

89 HR-MEF-OS, INSTITUT ZA SUDSKU MEDICINU I KRIMINALISTIKU UNIVERZITETA KR. JUGOSLAVIJE U ZAGREBU, Broj: 927/1944., IZVJEŠTAJ o radu Zavoda za sudsku medicinu i kriminalistiku za školsku godinu 1943/44. 
Premeru, koji tamo ostaje do 1952., kada ga mijenja Vladimir Palmović. ${ }^{90}$ Tim događajima prethodio je Miloslavićev odlazak. Naime, Miloslavić je 1944. otišao na liječenje u Baden kraj Beča. ${ }^{91}$ Bolovanje je opravdavao teškim ozljedama koje je zadobio kao član međunarodne komisije koja je istraživala zločine u Katynskoj šumi. Miloslavić je u Katynu bio od 28. do 30. travnja 1943. i ondje istraživao zločine koje je Crvena armija počinila nad poljskim časnicima i dočasnicima početkom 1940. godine. Po povratku u Zagreb održao je više predavanja i napisao nekoliko tekstova o toj temi. ${ }^{92}$ Danas je teško reći zašto je naveo da se ozlijedio tijekom boravka u Katynu jer o tome nema govora $\mathrm{u}$ drugim dostupnim izvorima ili literaturi. Osim toga po povratku u Zagreb nastavio je obavljati sve dužnosti koje je imao prije. Bilo kako bilo, može se reći da mu je odlazak vjerojatno spasio život. U prilog ovoj tvrdnji idu događaji vezani uz Ljudevita Juraka. Naime, po osnutku Demokratske Federativne Jugoslavije upravo će Jurak biti jedna od prvih žrtava novih vlasti. Jurak je sudjelovao u radu komisije koja je istraživala sovjetske zločine u Vinici. Kako nije htio povući zaključak o sovjetskom zločinu, 1945. pogubljen je u do danas nerazjašnjenim okolnostima. ${ }^{93}$ Treba reći i da su Miloslavić i Jurak bili dio komisije koja je 1944. istraživala stradanja u Kašini i okolici. Komisija je utvrdila trupla 38 osoba za koje se smatralo da su ih ubili partizani ujesen 1943. godine. ${ }^{94}$ Miloslavić će se po završetku rata vratiti u SAD, gdje će i umrijeti 1952. u St. Louisu.

\section{Zaključak}

Može se reći da je razvoj sudske medicine u Hrvatskoj od 1923. do 1945. ovisio o dva ključna elementa. Prvi je društveno-politička situacija. Međuljudski odnosi, političke nesnošljivosti, sveopća financijska oskudica i tek osnovani fakultet bitno su se odrazili i na razvoj sudske medicine. To se najbolje očitovalo u osnutku Zavoda za sudsku medicinu i kriminalistiku. Naime, Zavod je s radom započeo tek 1933., što je svakako utjecalo na sustavni pristup u razvoju sudske medicine kao znanstveno-nastavne discipline u Hrvatskoj. Međutim, važnu ulogu imala su i gibanja na globalnoj razini.

Druga važna stvar je ta što se sudska medicina, kao i medicinska znanost općenito, snažno počela razvijati već u XIX. stoljeću. To se unatoč svim poteškoćama očitovalo i na prostoru Hrvatske. Prve važnije publikacije koje se bave suvremenim pristupom u sudskoj medicini objavljuju u drugoj polovini XIX. stoljeća. Dolazak Ljudevita Juraka bio je važan iskorak za početak sustavnoga

90 ČEČUK, BELICZA, ŠKRBIĆ, Medicinski fakultet Sveučilišta u Zagrebu, 475.

${ }_{91}$ JAREB, Sovjetski zločin u Katynskoj šumi, 190-193; HR-MEF-OS, Broj: 137-1945., Predmet: Prof. dr. Miloslavić Eduard - prijedlog za produljenje dopusta, MINISTARSTVU NARODNE PROSVJETE Odjelu za visoku nastavu u Zagrebu.

92 JAREB, „Odjek zločina u Katynskoj šumi u tisku Nezavisne Države Hrvatske”, 119.

93 BELICZA, KRUŠLIN, 100 godina Kliničkog zavoda za patologiju, 55.

94 JAREB, Sovjetski zločin u Katynskoj šumi, 186-189. 
razvoja ne samo patologije nego i sudske medicine. On je kao cijenjeni stručnjak bitno utjecao na razvoj tih dviju grana medicine. To će se nastaviti i u kasnijim desetljećima. Pritom je osnivanje Zavoda 30-ih godina imalo ključnu ulogu. Miloslavićev dolazak i njegova nastojanja za pokretanje i opremanje Zavoda bitno su doprinijela razvoju sudske medicine u Hrvatskoj. Zavod se opremao različitom opremom i laboratorijima, a prvi je put bila osnovana i centralna ustanova za sudskomedicinske obdukcije koja je pokrivala potrebe Zagreba i središnje Hrvatske.

\section{Arhivski izvori}

HR-MEF: Hrvatska, Medicinski fakultet Sveučilišta u Zagrebu.

HR-UNIZG-OS: Hrvatska, Sveučilište u Zagrebu, Opći spisi (1918. - 1925.).

\section{Objavljeni izvori i tisak}

Alma mater Croatica: glasnik Hrvatskog sveučilišnog društva u Zagrebu (Zagreb), 1937, 1941.

Jutarnji list (Zagreb), 1918.

„Predstavka što nu ju je upravio akademički senat našeg sveučilišta na preuzv. gosp. bana i na sabor, kojom moli. da se u spomen 40-godišnice Njeg. Veličanstva ustroji na zagrebačkom sveučilištu medicinski fakultet”. S. l., s. a. [Zagreb, 1888]

Staleški glasnik: prilog Liječničkog vjesnika (Zagreb), 1923-1924.

Uredba medicinskih fakulteta. Sa svim saveznim propisima. Zagreb: Vlastita naklada [A. Šercera], 1937.

\section{Literatura}

BAZALA, Vladimir. Poviestni razvoj medicine u hrvatskim zemljama. Zagreb: Hrvatski izdavalački bibliografski zavod, 1943.

BELICZA, Biserka; ŠAIN, Snježana. „Uloga i doprinos Hrvatskog liječničkog zbora u osnivanju prosekture javnih zdravstvenih zavoda grada Zagreb g. 1913”. Liječnički vjesnik 120 (1998), br. 10-11: 349-355.

BELICZA, Mladen; KRUŠLIN, Božo. 100 godina Kliničkog zavoda za patologiju „Ljudevit Jurak” KBC-a „Sestre milosrdnice”. Zagreb: Klinički bolnički centar „Sestre milosrdnice”, 2014.

BERIĆ, Boris; BABIĆ, Nada. „Dr. Antun Lobmayer (1844-1906) - a pioneer of modern obstetrics and obstetrical education in Croatia”. Jugoslavenska ginekologija i opstetricija 19 (1979), br. 1-2: 113-118. Pristup ostvaren 11. 5. 2021. https://pubmed.ncbi.nlm.nih.gov/398912/.

ČAČKOVIĆ, Miroslav. „Kako da uredimo naš medicinski fakultet?” Liječnički vjesnik 39 (1917), br. 4: 146-150. Pristup ostvaren 28. 2. 2021. http://library.foi.hr/m3/casview.aspx?sql=SDCCDCYC9C7YDDDD4-DDD-SSDC46. 
„Čačković Vrhovinski, Miroslav”. U: Hrvatska enciklopedija, mrežno izdanje. Leksikografski zavod „Miroslav Krleža“. Pristupljeno 11. 5. 2021. http:// www.enciklopedija.hr/Natuknica.aspx?ID=13116.

ČEČUK, Ljubomir; BELICZA, Biserka; ŠKRBIĆ, Milan, ur. Medicinski fakultet Sveučilišta u Zagrebu. Zagreb: Stvarnost, 1985.

DUGAČKI, Vladimir. „Dr. Mavro Sachs (1817. - 1888.) - prvi medicinski docent Zagrebačkoga sveučilišta". Acta medico-historica Adriatica: AMHA 8 (2010), br. 2: 377-380. Pristup ostvaren 9. 3. 2021. https://hrcak.srce.hr/63544.

DUGAČKI, Vladimir. „Eduard Miloslavić, Zmaj od svete Mandaljene: svjedok istine o Katynskoj šumi”. U: Znameniti članovi Družbe „Braća Hrvatskoga Zmaja”. Znanstveni skup održan 7. lipnja 1997. u Zagrebu, ur. Alojz Getliher. Zagreb: Družba „Braća Hrvatskoga Zmaja”; Školska knjiga, 1997, 13-25.

DUGAČKI, Vladimir. „Medicinska nastava u Zagrebu prije otvorenja Medicinskog fakulteta”. Acta medico-historica Adriatica: AMHA 4 (2006), br. 1: 111-120. Pristup ostvaren 1. 3. 2021. https://hrcak.srce.hr/82425.

DUGAČKI, Vlatka; REGAN, Krešimir. „Zagreb u Prvom svjetskom ratu (Ozračje osnivanja medicinskog fakulteta)". Acta medico-historica Adriatica: AMHA 13 (2015), Supplement 1: 97-120. Pristup ostvaren 5. 3. 2021. https:// hrcak.srce.hr/148207.

GLESINGER, Lavoslav. Povijest medicine. Zagreb: Školska knjiga, 1978.

Godišnjak Hrvatskoga sveučilišta u Zagrebu za školske godine 1933/341938/39. Zagreb, 1940.

HABEK, Dubravko. „Prilog povijesti sudske medicine i mrtvozorstva u Bjelovaru". Arhiv za higijenu rada i toksikologiju 64 (2013), br. 3: 463-473. Pristup ostvaren 13. 5. 2021. https://hrcak.srce.hr/107638.

HLAVA, Jaroslav. „K ustrojenju novog medicinskog fakulteta u Zagrebu”. Liječnički vjesnik 39 (1917), br. 4: 143-146. Pristup ostvaren 28. 2. 2021. http://library.foi.hr/m3/casview.aspx?sql=SDCCDCYC9C7YDDDD4-DDD-SSDC43.

HORBEC, Ivana. Zdravlje naroda - bogatstvo države. Prosvijećeni apsolutizam i počeci sustava javnoga zdravstva u Hrvatskoj. Zagreb: Hrvatski institut za povijest, 2015.

JAREB, Mario. „Odjek zločina u Katynskoj šumi u tisku Nezavisne Države Hrvatske od travnja do lipnja 1943. godine”. Časopis za suvremenu povijest 30 (1998), br. 1: 117-129. Pristup ostvaren 11. 5. 2021. https://hrcak.srce. $\mathrm{hr} / 214409$.

JAREB, Mario. Sovjetski zločin u Katynskoj šumi: uloga doktora Eduarda Luke Miloslavića. Zagreb: AGM; Hrvatski institut za povijest, 2019.

„Jurak, Ljudevit”. U: Hrvatski biografski leksikon, mrežno izdanje. Leksikografski zavod „Miroslav Krleža”. Pristup ostvaren 11. 5. 2021. https://hbl. lzmk.hr/clanak.aspx?id=153.

KLÜVER, Heinrich. „Dr. Stephen Polyak, 1889-1955”. Journal of Neurophysiology 18 (1955), br. 3: 306. Pristup ostvaren 3. 3. 2021. https://journals. physiology.org/doi/abs/10.1152/jn.1955.18.3.306. 
Kraljevsko sveučilište Franje Josipa I. u Zagrebu (1874-1899). Zagreb: Akademički senat Kr. sveučilišta, 1900.

„Lobmayer, Antun”. U: Hrvatska enciklopedija, mrežno izdanje. Leksikografski zavod „Miroslav Krleža”. Pristup ostvaren 11. 5. 2021. http://www. enciklopedija.hr/Natuknica.aspx?ID=36934.

„Miler, Ernest”. U: Hrvatska enciklopedija, mrežno izdanje. Leksikografski zavod „Miroslav Krleža”. Pristup ostvaren 11. 5. 2021. http://www.enciklopedija.hr/Natuknica.aspx?ID=40840.

„Miloslavić, Eduard”. U: Hrvatska enciklopedija, mrežno izdanje. Leksikografski zavod „Miroslav Krleža“. Pristupljeno 18. 6. 2021. http://www.enciklopedija.hr/Natuknica.aspx?ID=40937.

„Osnova zakona o gradnji zgrada za medicinski fakultet i zemaljsku bolnicu s klinikama u Zagrebu”. Liječnički vjesnik 40 (1918), br. 40: 152-157. Pristup ostvaren 28. 2. 2021. http://library.foi.hr/lib/casopis.php?sqlx=S01101\&H $=\mathrm{hlz} \& \mathrm{E}=\& \mathrm{broj}=191804-05 \&$ sqlid $=1 \& \mathrm{U}=$.

PEĆINA, Marko; KLARICA, Marijan, ur. Medicinskifakultet Sveučilišta u Zagrebu (1917-2017). Zagreb: Sveučilište u Zagrebu, Medicinski fakultet, 2017.

„Poljak, Stjepan”. U: Hrvatska enciklopedija, mrežno izdanje. Leksikografski zavod „Miroslav Krleža”. Pristup ostvaren 3. 3. 2021. http://www.enciklopedija.hr/Natuknica.aspx?ID=49306.

„Rasprava o medicinskom fakultetu u hrv. saboru”. Liječnički vjesnik 39 (1917), br. 2: 44-81. Pristup ostvaren 25. 2. 2021. http://library.foi.hr/m3/casview.aspx?sql=SDCCDCYC9C7YDDDD2-DDD-SSDD44.

„Sergej Saltykow i njegov dolazak na Zavod za patologiju Medicinskog fakulteta u Zagrebu". Icarus Hrvatska - Priče iz arhiva. Pristup ostvaren 3. 3. 2021. https://www.icarushrvatska.hr/priceizarhiva/mef.

„Sudska medicina”. U: Hrvatska enciklopedija, mrežno izdanje. Leksikografski zavod „Miroslav Krleža”. Pristup ostvaren 9. 3. 2021. https://www.enciklopedija.hr/natuknica.aspx?id=58644.

„Sveučilište”. U. Hrvatska enciklopedija, mrežno izdanje. Leksikografski zavod „Miroslav Krleža”. Pristup ostvaren 11. 5. 2021. http://www.enciklopedija.hr/Natuknica.aspx?ID=59054.

Sveučilište Kraljevine Srba, Hrvata i Slovenaca u Zagrebu 1874-1924: spomenica Akademičkoga senata. Zagreb, 1925.

VITALE, Branko, ur. Četiri stoljeća javnog zdravstva $i$ biomedicine $u$ Hrvatskoj: mala zemlja duge medicinske tradicije u globalnoj medicini 21. stoljeća. Zagreb: Medicinska naklada; Akademija medicinskih znanosti Hrvatske, 2007.

ZEČEVIĆ, Dušan; BAKOVIĆ, Marija; BRKIĆ, Hrvoje; BUBALO, Pero; CRNIĆ, Ivica; FATOVIĆ-FERENČIĆ, Stella; KARIJA VLAHOVIĆ, Monika; KOVAČIĆ, Zdravko; KRIŽANAC, Šimun; KUBAT, Milovan; MAYER, Davor; NESTIĆ, Marina; PERIĆ, Tomislav; PETROVEČKI, Vedrana; POSPIŠIL 
ZAVRŠKI, Karla; STRINOVIĆ, Davor; SUTLOVIĆ, Davorka; ŠKAVIĆ, Josip; ŠKAVIĆ, Petar; ŠLAUS, Mario. Sudska medicina i deontologija. Zagreb: Medicinska naklada, ${ }^{5} 2018$.

ZIMOLO, Anton; JUKIĆ, Stanko; SEIWERTH, Sven; BATELJA, Lovorka. Prvih 85 godina. Zavod za patologiju Medicinskog fakulteta Sveučilišta u Zagrebu. Zagreb: Medicinska naklada, 2007. 


\section{SUMMARY}

\section{Forensic Medicine and the Medical School of the University of Zagreb (1922-1945)}

In this paper, the author analyses the position of forensic medicine at the Medical School of the University of Zagreb, focusing on the 1922-45 period. He also sketches the development of forensic medicine before the founding of the school. Emphasis is placed on significant events, such as the introduction of forensic medicine at the Faculty of Law of the University of Zagreb and the opening of the Pathology Unit of the Public Health Institutions of the City of Zagreb. After this, the author analyses the development of forensic medicine from the founding of the Medical School to the launching of the Institute of Forensic Medicine and Criminalistics. With the help of available literature and archival materials, the author has attempted to reconstruct the most important guidelines in the development of forensic medicine at the School of Medicine from 1922 to 1945. Financial troubles, a lack of adequate teaching cadres, and the complex sociopolitical situation greatly slowed the development of forensic medicine at the newly-founded school and characterised this period. A prominent role in introducing forensic medicine to the school was played by Ljudevit Jurak and Ernst Miller, who taught there from 1922 to 1932. Eduard Miloslavić took the leading role afterwards. He was appointed professor of forensic medicine in 1932, and in 1933 founded what is now the Institute of Forensic Medicine and Criminalistics. His arrival marked the launching of a systematic scientific-educational development of forensic medicine. Despite all problems, Miloslavić successfully secured a premises for the new Institute, launched the first laboratories, and acquired the needed equipment. Miloslavić left the Institute in 1944 and was succeeded by Ante Premeru in 1945.

Key words: forensic medicine; Institute of Forensic Medicine and Criminalistics; Eduard Miloslavić; Medical School of the University of Zagreb 